\title{
The Spatial Development for Rammang-Rammang Nature-Based Tourism Area in Maros Regency South Sulawesi
}

\author{
Nurul Wahdaniyah, Ismah Pudji Rahayu Ishak, Andi \\ Idham Asman \\ Urban and Regional Palnning \\ Alauddin State Islamic University of Makassar \\ Makassar, Indonesia \\ nurulwahdaniyah27@gmail.com
}

\author{
Despry Nur Annisa \\ Magister of Coastal and Watershed Management \\ Universitas Gadjah Mada Yogyakarta \\ Yogyakarta, Indonesia \\ despry.nur.a@mail.ugm.ac.id
}

\begin{abstract}
This research was conducted in RammangRammang Maros, South Sulawesi Province. RammangRammang located in Barrier Mountains Limestone (karst) Maros-Pangkep, precisely located in the village of the District Salenrang Bontoa, Maros. This attraction in the form of natural attractions and travel prehistoric prehistoric relics such as storing two caves which are prehistoric paintings / kepurbakala on cave walls. Attractions Karst Rammang-Rammang has a charming appeal and has a lot of tourists who come to visit this place but the object is not yet fully managed by the local government. In the management of tourism we need the concept of sustainable tourism. Sustainable tourism is tourism development that can be supported ecologically well as economically viable, as well as ethically and socially equitable for society. This particular study, then the direction of development of tourism in Rammang spatially-Rammang based on the judgment tourist attraction, power tamping space, and landscape of the area.This research resulted in the analysis that RammangRammang Region to be developed as a tourist area nature because it has feasibility level of $\mathbf{8 0 . 3 7 \%}$. The level of capacity in the tourist areas visitors Rammang-Rammang is 9899 people per day, while the maximum capacity is 18468 people. Based on the value of a tourist attraction and accommodation space, the landscape of the development direction of travel is divided into three zones namely reception zones, tourist zones, and zones of service.
\end{abstract}

Keywords-Spatial Development, Nature-based Tourism, and Rammang-Rammang

\section{INTRODUCTION}

The tourism is one of the sectors of development that can spur economic development in a region (Soemardjan, 1977: 58). This is due to the tourism has three aspects namely economic aspects (source of foreign exchange, taxes), social aspects (job creation) and cultural aspects (Hartono, 1974: 45). The tourism sector is the largest and strongest Industry in the financing of the global economy. The economic sector will be a key to improve the world economy in the 21 st century, and become one of the global industry.

Maros is one of regency in South Sulawesi which develop in many sectors, such as agriculture, the economy, education and tourism. By looking at developments in some sectors, Maros has the potential in region of tourism development. One of Maros attractions is Leang Akkarrasa RammangRammang's prehistoric cave in the village Salenrang of the Bontoa sub-regency. Bontoa sub-regency in term of Regional Planning Document in Maros Regency belong to heritage preserve, geological protected area, protected forest and prehistoric attraction area.

Rammang-Rammang tourism is in the cluster of Mountains Limestone (karst) Maros-Pangkep, in the village Salenrang Bontoa sub-regency, Maros Regency. This tourism is a natural attraction and prehistoric atraction because it has two caves where there are prehistoric paintings on the walls of the cave. Karst Rammang-Rammang tourism has a beatiful attraction and there is already a lot of tourists who come to visit this place but this tourism is not yet fully managed by the local government.

By looking at the existing natural potential in Maros regency then the spesific planning should be done to develop the potential of the attraction in this area. The direction of this natural tourism development is required to achieve sustainability of that area. The main achievement in the direction of this natural tourism in case study is based on an assessment of the analysis of attraction and the carrying capacity of tourist areas. Through this study it is expected that tourism development is managed by maintaining the aesthetics of the attractions. Beside that the direction of this development can also support economic development in the tourism area and Maros Regency.

\section{METHOD}

The methods of data collection which is used in the study, is observation, interview, and literature study. And then there are also analytical methods which are used which.

\section{A. Analysis of tourist attraction}

In the area of sustainable tourism development analysis of tourist attraction is needed because every area has its own attraction. To perform the analysis of a tourist attraction it is 
necessary data such as ratings of criteria attractions, infrastructure, and accessibility in attraction area.

Objects and attractions (flora, fauna and other objects) that have been obtained and analyzed in accordance with the criteria of scoring from Guidance of Analysis of Regional Operation Objects and The Attraction of Natural Tourism Director General PHKA 2003. Amount of value for the assessment criteria ODTWA can be calculated by the following formula:

$$
\begin{array}{ll}
\text { Note: } & \mathrm{S}=\mathrm{N} \times \mathrm{B} \\
\mathrm{S}= & \text { Score on criteria } \\
\mathrm{N}= & \begin{array}{l}
\text { Amount of value of the elements on } \\
\text { criteria }
\end{array} \\
\mathrm{B} \quad=\text { Amount of score }
\end{array}
$$

Karsudi,.et al (2010) declared after comparison, it will obtain feasibility index in percent. Index feasibility of an ecotourism area are as follows:

- The level of eligibility> $66.6 \%$ : is eligible to be developed, with the criteria of a tourist area that has potential, high infrastructure based on the parameters that have been established and supported by the accessibility.

- eligibility rate of $33.3 \%-66.6 \%$ : is not yet eligible to be developed, with the criteria of a tourist area that has the potential, the facilities and infrastructure that are based on the parameters that have been established and supported by adequate accessibility.

- The level of feasibility <33.3\%: is not eligible to be developed, with the criteria of a tourist area that has potential, low infrastructure based on the parameters that have been established and inadequate accessibility.

\section{B. Analysis of the carrying capacity of tourist areas}

The development of the tourism sector increases continuously, it is seen by the increasing number of visitors. Increasing of visitors must be accompanied by a good planning of tourism area in accordance with the maximum number of visitors. To determine the carrying capacity of travel using the following formula.

$$
\mathrm{DD}=\frac{\mathrm{A}}{\mathrm{S}}
$$

\begin{tabular}{|c|c|c|c|}
\hline No & Activity & Facility & Standard \\
\hline 1 & swimming (free) & - & $15 \mathrm{~m}^{2}$ \\
\hline 2 & On boat & quay, locket, boat & $\begin{array}{l}2 \text { unit/Ha (1 unit } \\
=20 \text { people) }\end{array}$ \\
\hline 3 & Fishing & Fishing deck & $10 \mathrm{~m}^{2} /$ person \\
\hline 4 & Picnic & Picnic Area & 100 people/Ha \\
\hline 5 & Culinary tour & Restaurant & $4 \mathrm{~m}^{2} /$ person \\
\hline 6 & Shopping tour & Souvenir shop & $1,5 \mathrm{~m}^{2} /$ person \\
\hline 7 & Cycling & $\begin{array}{l}\text { Locket bicycle rentals, } \\
\text { bicycle route, marker } \\
\text { boards }\end{array}$ & $\mathrm{m}^{2} /$ person \\
\hline 8 & Playing & Playground & $6 \mathrm{~m}^{2}$ \\
\hline 9 & Stroll & $\begin{array}{l}\text { pedestrian, marker } \\
\text { boards }\end{array}$ & $6 \mathrm{~m}^{2} /$ person \\
\hline 10 & $\begin{array}{l}\text { Watched the cultural } \\
\text { and artistic } \\
\text { performances }\end{array}$ & $\begin{array}{l}\text { Theater, hall, culture } \\
\text { and art }\end{array}$ & $2 \mathrm{~m}^{2} /$ person \\
\hline 11 & $\begin{array}{l}\text { See exhibition of } \\
\text { product, art and } \\
\text { culture }\end{array}$ & hall, culture and art & $4 \mathrm{~m}^{2} /$ person \\
\hline 12 & $\begin{array}{l}\text { Reduce the } \\
\text { greenhouse effect and } \\
\text { strawberry garden } \\
\text { (agrotourism) }\end{array}$ & $\begin{array}{l}\text { Greenhouse, } \\
\text { strawberry }\end{array}$ & $9 \mathrm{~m}^{2} /$ person \\
\hline
\end{tabular}

Note :

DD : Carrying capacity

A : Area that is used by tourist

S : Individual evenly Standard
TABLE I STANDARD OF NECESSARY AN ACTIVE TOURISM

TABLE II. STANDARD OF NECESSARY A PASSIVE TOURISM

\begin{tabular}{llll}
\hline No & Activity & Facility & Standard \\
\hline 1 & Enjoy the view & Shelter, gazebo & $4 \mathrm{~m}^{2} /$ person \\
3 & Take a rest & park & \\
\hline & & & b. Source : Results of analysis 2016
\end{tabular}

- Coefficient of Rotation (K)

$\mathrm{K}=\underline{\mathrm{N}}$

$\mathrm{R}$

Note:

$\mathrm{K}$ = Coefficient of Rotation

$\mathrm{N}=$ Visiting hour per a day in area which is used (6 hours/person)

$\mathrm{R}=$ Evently visiting time (4 hours/person)

- Number of visitors per a day which is expected

$\mathrm{T}=\mathrm{DD} \times \mathrm{K}$

Note:

$\mathrm{T}=$ Number of visitors per a day which is expected

DD = Carrying Capacity

$\mathrm{K}=$ Coefficient of Rotation

\section{Analysis of Landscape Region}

Landscape refers to compositions of soils in a area and its visual representation. Term Landscape interpret the composition of soil visually, because this is the main way how is the Landscape perceived. The character of Landscape appears because of the power of its own establishment, either be element or natural process which is functional (ecological aspect) and also because of human influence (cultural aspect). The planning of the Landscape intend to take long term decision in order to obtain a model of the landscape or landscape functional, aesthetic, which support many humans 
needs and his desires in order to improve the comfort and prosperity (Nurisjah, 2007). In the analysis of this landscape,the direction tourism development in Rammang Rammang is visualized in form spatial mapping.

\section{RESULT AND DISCUSSION}

Rammang-Rammang tourism is in the cluster of Mountains Limestone (karst) Maros-Pangkep, in the village Salenrang Bontoa sub-regency, Maros Regency, South Sulawese province. It is $40 \mathrm{~km}$ north from Makassar city, and can be No reached via landline by using motor vehicle with time $e_{1}$ expedition around 2 hours from Makassar city. The tourism is natural attraction and very easy to be reached because it is near 3 from inter-provincial highways.

Prehistoric sites from Rammang-Rammang is a series of river Pute trip, in this place there are about three prehistoric cave sites, each of which has a different legacy. Compared with the relics of cave paintings that are found in Leang-Leang and describe the life activity of hunting in low-lying areas which are characterized by their paintings hog deer, sites prehistoric caves in rammang-rammang has relics cave paintings which describe the activity of hunting on coast and sea coast because in this place cave paintings in the form of boat, man who carries the spear and riding a boat, turtles and fish are found. The combination of alluring landscapes and relics of prehistoric caves further add to the appeal of tourism.
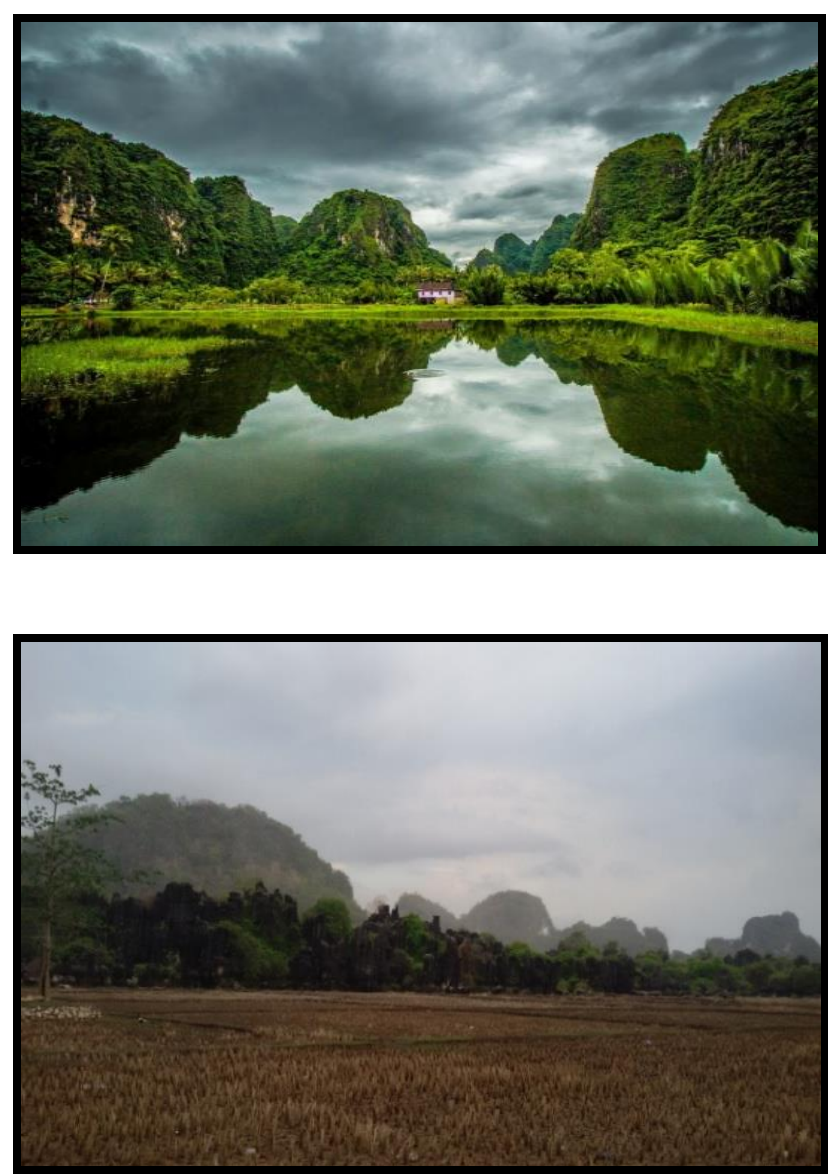

Fig. 1. Tourism Karst Rammang-Rammang

\section{A. Analysis of Tourist Attractions In Karst Rammang- Rammang}

Criteria of appeal by 6 because the appeal is a major factor reasons people travel. The results of the feasibility index Rammang-Rammang tourist areas are as follows:

TABLE III. RESULT OF ASSESSMENT OCJECT AND ATTRACTION IN KARST RAMMANG-RAMMANG AREA

\begin{tabular}{lllllll}
$\begin{array}{l}\text { Element/Sub } \\
\text { element }\end{array}$ & Amount & Value & Score & $\begin{array}{l}\text { Maximum } \\
\text { Skore }\end{array}$ & $\begin{array}{l}\text { Indeks } \\
(\%)\end{array}$ & Explanation \\
\hline Attraction & 6 & 130 & 780 & 900 & 86,67 & Feasible \\
Accessibility & 5 & 85 & 425 & 450 & 94,44 & Feasible \\
$\begin{array}{l}\text { Facilities and } \\
\text { Infrastructures }\end{array}$ & 3 & 60 & 180 & 300 & 60 & $\begin{array}{l}\text { Not } \\
\text { Feasible }\end{array}$ \\
Feasibility Level & & 1.385 & & 80,37 & Feasible \\
\hline
\end{tabular}

From the results of an assessment of the object and appeal of the Karst Rammang-Rammang is rated by the level of attractiveness, accessibility and facilities / infrastructure to produce a total score of 1385 with a feasibility level of $80.37 \%$. Based on the feasibility index, natural Tourism Rammang Rammang area have a feasibility level $80.37 \%$, which means that this area deserves to be developed.

\section{B. Analysis of the carrying capacity of tourist areas}

Results of capacity analysis of natural Tourism Rammang Rammang area are as follows:

TABLE IV. STANDARD OF NECESSARY AN ACTIVE TOURISM

\begin{tabular}{|c|c|c|c|c|c|c|}
\hline No & Activity & Facility & Standard & Large & $\begin{array}{l}\text { Carrying } \\
\text { Capacity }\end{array}$ & $\begin{array}{l}\text { Total } \\
\text { visitors }\end{array}$ \\
\hline 1 & $\begin{array}{l}\text { Swimming } \\
\text { (free) }\end{array}$ & - & $15 \mathrm{~m}^{2}$ & $\begin{array}{l}1450 \\
\mathrm{~m}^{2}\end{array}$ & 97 & 145 \\
\hline 2 & On boat & $\begin{array}{l}\text { quay, } \\
\text { locket, } \\
\text { boat }\end{array}$ & $\begin{array}{l}2 \text { unit/Ha } \\
(1 \text { unit = } \\
20 \\
\text { people) }\end{array}$ & $\begin{array}{l}3,847 \\
\mathrm{Ha}\end{array}$ & 38 & 57 \\
\hline 3 & Fishing & $\begin{array}{l}\text { Fishing } \\
\text { deck }\end{array}$ & $\begin{array}{l}10 \\
\mathrm{~m}^{2} / \text { perso } \\
\mathrm{n}\end{array}$ & $\begin{array}{l}20.690 \\
\mathrm{~m}^{2}\end{array}$ & 2.069 & 3.103 \\
\hline 4 & Picnic & $\begin{array}{l}\text { Picnic } \\
\text { Area }\end{array}$ & $\begin{array}{l}100 \\
\text { people/H } \\
\text { a }\end{array}$ & $\begin{array}{l}1,025 \\
\mathrm{Ha}\end{array}$ & 102 & 153 \\
\hline 5 & $\begin{array}{l}\text { Culinary } \\
\text { tour }\end{array}$ & $\begin{array}{l}\text { Restaur } \\
\text { ant }\end{array}$ & $\begin{array}{l}4 \mathrm{~m}^{2} / \\
\text { person }\end{array}$ & $\begin{array}{l}1.270 \\
\mathrm{~m}^{2}\end{array}$ & 317 & 475 \\
\hline 7 & Cycling & $\begin{array}{l}\text { Souven } \\
\text { ir shop }\end{array}$ & $\begin{array}{l}\mathrm{m}^{2} / \\
\text { person }\end{array}$ & $750 \mathrm{~m}^{2}$ & 750 & 1.125 \\
\hline 8 & Playing & $\begin{array}{l}\text { Locket } \\
\text { bicycle } \\
\text { rentals, } \\
\text { bicycle } \\
\text { route, } \\
\text { marker } \\
\text { boards }\end{array}$ & $6 \mathrm{~m}^{2}$ & 570 & 95 & 142 \\
\hline 9 & Stroll & $\begin{array}{l}\text { Playgr } \\
\text { ound }\end{array}$ & $\begin{array}{l}6 \mathrm{~m}^{2} / \\
\text { person }\end{array}$ & $975 \mathrm{~m}^{2}$ & 162 & 243 \\
\hline 10 & $\begin{array}{l}\text { Watched } \\
\text { the cultural } \\
\text { and artistic } \\
\text { performanc } \\
\text { es }\end{array}$ & $\begin{array}{l}\text { pedestr } \\
\text { ian, } \\
\text { marker } \\
\text { boards }\end{array}$ & $\begin{array}{l}2 \mathrm{~m}^{2} / \\
\text { person }\end{array}$ & $960 \mathrm{~m}^{2}$ & 480 & 720 \\
\hline 11 & $\begin{array}{l}\text { See } \\
\text { exhibition }\end{array}$ & $\begin{array}{l}\text { Theater } \\
\text {, hall, }\end{array}$ & $\begin{array}{l}4 \mathrm{~m}^{2} / \\
\text { person }\end{array}$ & $960 \mathrm{~m}^{2}$ & 480 & 720 \\
\hline
\end{tabular}




\begin{tabular}{|c|c|c|c|c|c|c|}
\hline No & Activity & Facility & Standard & Large & $\begin{array}{l}\text { Carrying } \\
\text { Capacity }\end{array}$ & $\begin{array}{l}\text { Total } \\
\text { visitors }\end{array}$ \\
\hline & $\begin{array}{l}\text { of product, } \\
\text { art and } \\
\text { culture }\end{array}$ & $\begin{array}{l}\text { culture } \\
\text { and art }\end{array}$ & & & & \\
\hline 12 & $\begin{array}{l}\text { field } \\
\text { (agrotouris } \\
\text { m) }\end{array}$ & Field & $\begin{array}{l}9 \\
\mathrm{~m}^{2} / \text { perso } \\
\mathrm{n}\end{array}$ & $\begin{array}{l}47.810 \\
\mathrm{~m}^{2}\end{array}$ & 5.312 & 7.968 \\
\hline Total & & & & & 9.422 & 14.131 \\
\hline
\end{tabular}

TABLE V. STANDARD OF NECESSARY A PASSIVE TOURISM

\begin{tabular}{|c|c|c|c|c|c|c|}
\hline No & Activity & Facility & Standard & Large & $\begin{array}{l}\text { Carrying } \\
\text { Capacity }\end{array}$ & $\begin{array}{l}\text { Total } \\
\text { visitors }\end{array}$ \\
\hline 1 & $\begin{array}{l}\text { Enjoy } \\
\text { the } \\
\text { view }\end{array}$ & $\begin{array}{l}\text { Shelter, } \\
\text { gazebo }\end{array}$ & $\begin{array}{l}4 \mathrm{~m}^{2} / \\
\text { person }\end{array}$ & $\begin{array}{l}1.050 \\
\mathrm{~m}^{2}\end{array}$ & 262 & 393 \\
\hline 2 & $\begin{array}{l}\text { Take a } \\
\text { rest }\end{array}$ & Park & & $\begin{array}{l}860 \\
m^{2}\end{array}$ & 215 & 322 \\
\hline Total & & & & & 477 & 715 \\
\hline
\end{tabular}

- Coefficient of Rotation $(\mathrm{K})$

$$
\mathrm{K}=\underline{\mathrm{N}}
$$$$
\mathrm{K}=\underline{6}=1,5
$$

Note:

$\mathrm{K}=$ Coefficient of rotation

$\mathrm{N} \quad=$ Visiting hour per a day in area which is used (6 hours/person)

$\mathrm{R} \quad=$ Evently visiting time (4 hours/person)

- Number of visitors per a day which is expected

$\mathrm{T}=\mathrm{DD} \times \mathrm{K}$

$\mathrm{T}=9.899 \times 1,5$

$\mathrm{T}=14.848$

Note:

$\mathrm{T}=$ Number of visitors per a day which is expected

DD = Carrying Capacity

$\mathrm{K}=$ Coefficient of Rotation

From the analysis above it can be seen that the capacity of the visitors is 9.899 people, while the maximum capacity is 14.848 people.

\section{Analysis of Landscape}

Based on analysis of attraction is the landscape analysis for the development of natural tourism Rammang-Rammang divided according to function with some travel in space as follows:

\section{1) Reception Room}

This space is the space that serves as the entrance to the area. In this space are welcoming facilities helded to greet the visitors. The means for reception room in the Karst RammangRammang is in the form of the gate and a parking lot with an area of 0.48 hectares.

\section{2) Space or Space Transition Services}

This space serves as a recognition before the visitor feel the change in atmosphere between the areas outside and the inside area. In this space visitors will also get information on the area and the lives of the surrounding community. Such information can be submitted with information boards or by providing information on the space center.

The planning of service room are:

TABLE VI. SERVICE SPACE SIZE

\begin{tabular}{lll}
\hline No & Service Facilities & Large $(\mathrm{Ha})$ \\
\hline 1. & Quay & 0,23 \\
2. & Centre of information & 0,17 \\
3. & Settlement & 0,91 \\
Total & & 1,91 \\
\hline & & \multicolumn{2}{c}{ e. Source: Result of Analysis 2016 }
\end{tabular}

\section{3) Travel Zone}

This space is the space in which all activities conducted tours. The room is divided into two types namely the land and water travel. The plan of space travel as follows:

TABLE VII. TOURISM SPACE SIZE

\begin{tabular}{clc}
\hline No & Tourism Space & Large $(\mathbf{H a})$ \\
\hline 1. & Picnic Area & 1,05 \\
2. & Gazebo & 0,10 \\
3. & Garden & 0,14 \\
4. & Stall & 0,13 \\
5. & Pool & 0,10 \\
6. & Field & 0,09 \\
7. & Rental bicycle & 0,07 \\
8. & Worship place & 0,70 \\
9. & River & 3,84 \\
10. & Stone Park & 40,58 \\
11. & Playground & 0,057 \\
12. & Restaurant & 0,70 \\
13. & Fishing place & 2,07 \\
14. & Home stay & 1,144 \\
15. & Toilet & 0,03 \\
Total & & $\mathbf{5 0 , 1 0 1}$ \\
\hline & & f. Source: Result of Analysis 2016
\end{tabular}




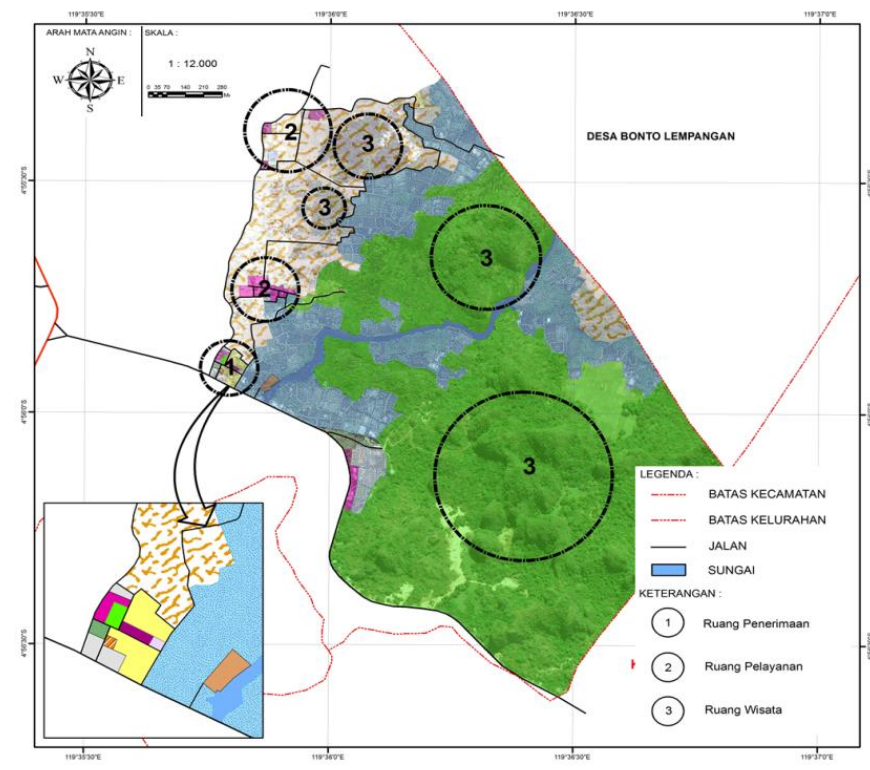

Fig. 2. Spatial Development Map Based on Landscape Area of RammangRammang

\section{4) Buffer Zone}

Buffer zone is a space that serves to provide protection against tourist areas. The plan of buffer space in the Karst Rammang-Rammang is an area of 119.81 hectares.

\section{CONCLUSION}

Based on the description above discussion, the conclusions of this study are as follows:

a. Rammang Rammang area is worthy to be developed as a natural tourism area because it has feasibility level of $80.37 \%$.

b. The results of the analysis of the capacity level of the visitors in tourism Rammang-Rammang area is 9899 people per day, while the maximum capacity is 14.468 people.

c. The needs for regional landscape planning in order to provide direction spatially tourism development.

\section{REFERENCE}

Darsoprajitno Soewarno, 2013, Ekologi Pariwisata, Penerbit Angkasa Bandung, Bandung

Hartono, Hari. 1974. Perkembangan Pariwisata, Kesempatan Kerja, dan Permasalahannya. Prisma Th. III No. 2.

Karsudi, R. Soekmadi, H. Kartodiharjo. 2010. Strategi Pengembangan Ekowisata di Kabupaten Kepulauan Yapen Provinsi Papua. IPB. Bogor. 